\title{
Prevalence and Characteristics of Rheumatoid-Associated Autoantibodies in Patients with COVID-19
}

\author{
Chen $\mathrm{Xu}^{\mathrm{l}, *}$ \\ Junli Fan ${ }^{1, *}$ \\ Yi Luol,* \\ Ziwu Zhaol,* \\ Peng Tang ${ }^{1} *$ \\ Gui Yang (D) \\ Yunbao Pan (iD) \\ Shuang Guo' \\ Yingjuan Liu' \\ Yong Xiong ${ }^{2}$ \\ Wen $X_{i e}{ }^{1}$ \\ Xinghua Long $\mathbb{D}^{\prime}$ \\ 'Department of Laboratory Medicine, \\ Zhongnan Hospital of Wuhan University, \\ Wuhan, People's Republic of China; \\ ${ }^{2}$ Department of infectious diseases, \\ Zhongnan Hospital of Wuhan University, \\ Wuhan, People's Republic of China \\ *These authors contributed equally to \\ this work
}

Objective: Patients with rheumatic immune diseases were more likely to develop severe or critical COVID-19. We aimed to determine whether rheumatoid factor antibodies were present in COVID patients and the level and type of rheumatoid factor antibodies produced in COVID-19 patients were related to the degree of the patient's condition. The study also aimed to determine the prevalence and characteristics of rheumatoid factor antibodies in patients with COVID-19.

Methods: Sera collected from 129 patients with COVID-19 were tested for rheumatoid factor antibodies by ELISA. Five patients were tracked for several months to monitor dynamic changes of these antibodies.

Results: Rheumatoid-associated autoantibodies were detected in $20.16 \%$ of patients (26/ 129) following infection with severe acute respiratory syndrome coronavirus 2 (SARS-CoV -2). In addition, IgM-RF was primarily present in critically ill patients, while IgA-RF was mainly present in mild patients. Five patients were able to track for several months to monitor dynamic changes of these antibodies. Rheumatoid factor antibodies peaks in the later phase of the disease and last for longer time. Anti-Jo-1 antibody was found in one of the five patients.

Conclusion: This was the case series report that rheumatoid-associated autoantibodies are present in patients with COVID-19. The clinical significance of these antibodies was not fully understood and needed further characterization. These autoantibodies are related to the severity of the patient's disease and exist for a long time in the patient's body, while their impact on the patient's health is unknown.

Keywords: rheumatoid factor, IgA-RF, IgG-RF, IgM-RF, anti-Jo-1, COVID-19, SARS-CoV-2
Correspondence: Xinghua Long; Wen Xie Department of Laboratory Medicine, Zhongnan Hospital of Wuhan University, Wuhan, People's Republic of China Email zhoulongxinghua@qq.com; whxw007@I26.com

\section{Introduction}

SARS-CoV-2, formerly known as 2019-nCoV, is a newly emerging virus belonging to the Coronaviridae family. The common signs of infection with coronavirus include respiratory symptoms, fever, cough, shortness of breath, and dyspnea. In more severe cases, the infection can lead to pneumonia, severe acute respiratory syndrome, kidney failure, and even death. The computerized tomographic chest scan is usually abnormal even in those with no symptoms or mild disease. Patients with COVID-19 are primarily immune responses to cytokines and inflammatory storms. They show a decrease in lymphocytes, especially natural killer cells. Levels of interleukin-6, D-dimer, C-reactive protein and serum amyloid A were elevated, and the Prothrombin time was prolonged. The clinical features of 5 rheumatic immune disease 
patients with the simultaneous presence of COVID-19 have been reported. ${ }^{1}$ As a result, patients with rheumatic immune diseases were more likely to develop severe or critical COVID-19. Rheumatoid factor (RF) is a kind of autoantibody produced in rheumatic immune disease, can be seen in a variety of systemic autoimmune diseases and infectious diseases, and can be detected in healthy people. However, the large number of high-affinity RF found in patients with chronic diseases may be harmful due to its involvement in stimulating autologous lymphocytes and/or deposition in the blood vessels, leading to vasculitis and resulting in a vicious cycle of autoantibodies. ${ }^{2}$ In our study, we are trying to find whether rheumatoid factors are present in COVID-19 patients. Does the level and type of rheumatoid factors produced in COVID-19 patients reflect the severity of the disease? This was the first report that rheumatoid-associated autoantibodies are found in COVID-19 patients without a history of rheumatoid arthritis.

\section{Methods}

Clinical records and laboratory results were retrospectively reviewed for 129 patients admitted to Zhongnan Hospital of Wuhan University from Jan. 30 to Mar. 9, 2020 who were confirmed COVID-19 based on symptoms, chest computed tomography, and positive RT-PCR results. Patients with history of rheumatoid arthritis were excluded in the study.

Quantitative RT-PCR for SARS-CoV-2 nucleic acid (RTPCR Kit, BioGerm) was conducted on throat swabs. Serum $\mathrm{RF}$ and $\mathrm{aCL}$ antibodies (IgA, IgG, and IgM) were determined by ELISA (AESKU). The cutoff values for positivity were set $>18 \mathrm{kU} / \mathrm{L}$ based on manufacturer's recommendations. ANA and ENA tests were done by Immunofluorescence and immunoblotting (Euroimmun). CCP were determined by ELISA (Euroimmun). Lymphocyte subsets were detected using BD instruments and reagents and were obtained from whole blood samples. The values of D-dimer, SAA and CRP were measured using a Beckmann biochemical analyzer. Serum was used for SAA and CRP testing, and plasma was used for D-dimer testing. Graphs are drawn by GraphPad Prism 8.

\section{Ethical Approval}

This study was reviewed and approved by the Ethical Committee of Zhongnan Hospital of Wuhan University. This was a retrospective study, written informed consent was waived by the Ethics Commission of the designated hospital for emerging infectious diseases. The data complies with the Declaration of Helsinki.

\section{Results}

We first determined the prevalence and features of RFs in patients with COVID-19. When the manufacturer's recommended cut-off value of $>18 \mathrm{kU} / \mathrm{L}$ was utilized, RFs were detected in $20.16 \%$ of the COVID patients (26/129) (Table 1).

Dynamic changes in the levels of RFs in five COVID19 patients were further investigated. Within a few months after discharge, the RFs' levels of five patients were monitored. Among these five patients, three are mild COVID, two are critically ill and admitted to ICU.

The first patient was admitted to the hospital on February 8, 2020. A chest CT showed an abnormal density of the upper lobe, patchy shadow of the left upper lobe of the lung. The nucleic acid test for SARS-CoV-2 RNA of the patient was positive, combined with imaging results, exposure history, and clinical symptoms, the patient was confirmed as COVID-19, other laboratory tests are shown in Table 2. The patient was also found anti-Jo-1 antibody positive. The level of Jo-1 was still increased for some time even after recovery and discharged from hospital and then decreased in the later reexamination.

The second patient was a 37-year-old female with no apparent discomfort since infection. She was admitted to the hospital on February 12, 2020. The third patient was a 61-year -old male who was admitted to the hospital on January 21, 2020. A chest CT showed patchy changes in both lungs.

The fourth patient was a 79-year-old severe woman who was admitted to the hospital on February 02, 2020. The patient had fever, diarrhea, multiple ground glass density shadows could be seen on lung CT. The patient's condition deteriorated after admission, with reduced lymphocyte count, increased levels of IL-6, C-reactive protein (CRP), D-dimer, and Serum amyloid A (SAA). The fifth patient was a severe patient with symptoms of fatigue, diarrhea and dyspnea, and

Table I Prevalence and Characteristics of Rheumatoid Factor Antibodies in Patients with COVID-19

\begin{tabular}{|l|l|}
\hline Rheumatoid Factor Antibodies & COVID (n=I 29) \\
\hline Overall prevalence in any RFs, $n(\%)$ & $26(20.16)$ \\
RF-IgA & $13(10.32)$ \\
RF-IgG & $8(6.35)$ \\
RF-IgM & $12(9.52)$ \\
RF-IgA +RF-IgG & $1(0.78)$ \\
RF-lgA +RF-IgM & $2(1.55)$ \\
RF-IgG+RF-IgM & $2(1.55)$ \\
RF-lgA +RF-IgG+RF-IgM & $1(0.78)$ \\
\hline
\end{tabular}

Note: The cutoff values for positivity in all rheumatoid factor antibodies were set $>18 \mathrm{kU} / \mathrm{L}$ based on the recommendations of the manufacturer. 
Table 2 Demographic and Clinical Characteristics and Laboratory Findings

\begin{tabular}{|c|c|c|c|c|c|}
\hline Characteristic & Patient I & Patient 2 & Patient 3 & Patient 4 & Patient 5 \\
\hline \multicolumn{6}{|c|}{ Demographic characteristics } \\
\hline Age $-y r$ & 41 & 37 & 62 & 79 & 61 \\
\hline Sex & Female & Female & Male & Female & Male \\
\hline \multicolumn{6}{|l|}{ Initial findings } \\
\hline Medical history & $\begin{array}{l}\text { Healthy without rheumatoid } \\
\text { arthritis }\end{array}$ & $\begin{array}{l}\text { Healthy } \\
\text { without } \\
\text { rheumatoid } \\
\text { arthritis }\end{array}$ & $\begin{array}{l}\text { Healthy } \\
\text { without } \\
\text { rheumatoid } \\
\text { arthritis }\end{array}$ & $\begin{array}{l}\text { Hypertension, no } \\
\text { history of } \\
\text { rheumatoid } \\
\text { arthritis }\end{array}$ & $\begin{array}{l}\text { Cholecystectomy, chronic } \\
\text { gastritis, no history of } \\
\text { rheumatoid arthritis }\end{array}$ \\
\hline Disease severity & Moderate & Mild & Moderate & Severe & Severe \\
\hline $\begin{array}{l}\text { Symptoms at } \\
\text { disease onset }\end{array}$ & $\begin{array}{l}\text { Fever, cough, fatigue, muscle } \\
\text { soreness, headache }\end{array}$ & Normal & $\begin{array}{l}\text { Paroxysmal } \\
\text { dry cough }\end{array}$ & $\begin{array}{l}\text { Nausea, poor } \\
\text { appetite, occasional } \\
\text { vomiting }\end{array}$ & $\begin{array}{l}\text { Fatigue, diarrhea and } \\
\text { dyspnea. }\end{array}$ \\
\hline Imaging features & $\begin{array}{l}\text { Abnormal density of the upper } \\
\text { lobe, Patchy shadow of left } \\
\text { upper lobe of lung }\end{array}$ & Normal & $\begin{array}{l}\text { Patchy } \\
\text { changes in } \\
\text { both lungs }\end{array}$ & $\begin{array}{l}\text { Multiple infection } \\
\text { foci in both lungs }\end{array}$ & $\begin{array}{l}\text { Fibrous proliferative foci in } \\
\text { both upper lobes of lung }\end{array}$ \\
\hline \multicolumn{6}{|c|}{ Laboratory findings (Reference range) } \\
\hline $\begin{array}{l}\text { Total lymphocytes } \\
\left(\text { per } \mathrm{mm}^{3}\right)(1100- \\
3200)\end{array}$ & 1070 & 1270 & 1000 & 510 & 400 \\
\hline $\begin{array}{l}\text { Globulin (g/liter) } \\
(20-30)\end{array}$ & 26.5 & 24.6 & 27.9 & 30.6 & 28.3 \\
\hline $\begin{array}{l}\text { Alanine } \\
\text { aminotransferase } \\
(\mathrm{U} / \text { liter })(7-45)\end{array}$ & 30 & 20 & 23 & 15 & 110 \\
\hline $\begin{array}{l}\text { Aspartate } \\
\text { aminotransferase } \\
\text { (U/liter) (13-35) }\end{array}$ & 27 & 16 & 27 & 34 & 52 \\
\hline $\begin{array}{l}\text { C-reactive protein } \\
(\mathrm{mg} / \text { liter })(0-10)\end{array}$ & 12 & 2 & 20.7 & 39.3 & 8.2 \\
\hline $\begin{array}{l}\text { Serum amyloid } \\
\text { A (mg/liter) }(0-10)\end{array}$ & 45.95 & 25.39 & 167.56 & 237.58 & 139.83 \\
\hline $\begin{array}{l}\text { D-dimer (mg/liter) } \\
(0-0.5)\end{array}$ & 0.161 & 0.089 & 0.419 & 6.576 & 11.902 \\
\hline $\begin{array}{l}\text { Prothrombin time } \\
\text { (sec) }(9.4-12.5)\end{array}$ & 12.8 & 12 & 12.6 & 10.8 & 17 \\
\hline $\begin{array}{l}\text { Anti-cardiolipin } \\
\text { antibody }(0-12)\end{array}$ & $\begin{array}{l}\operatorname{lgA} 0.73(\mathrm{APL} / \mathrm{mL}) \\
\operatorname{lgG} \quad 1.13(\mathrm{GPL} / \mathrm{mL}) \\
\lg \mathrm{I} \quad 1.82(\mathrm{MPL} / \mathrm{mL})\end{array}$ & $\begin{array}{c}\lg A 9.88(\mathrm{APL} / \\
\mathrm{mL}) \\
\lg \mathrm{g} 0.52 \\
(\mathrm{GPL} / \mathrm{mL}) \\
\operatorname{lgM} 1.39 \\
(\mathrm{MPL} / \mathrm{mL})\end{array}$ & $\begin{array}{c}\operatorname{lgA} 8.37(\mathrm{APL} / \\
\mathrm{mL}) \\
\operatorname{lgG~I.87} \\
(\mathrm{GPL} / \mathrm{mL}) \\
\operatorname{lgM} 0.56 \\
(\mathrm{MPL} / \mathrm{mL})\end{array}$ & $\begin{array}{c}\operatorname{lgA} I .83(\mathrm{APL} / \mathrm{mL}) \\
\operatorname{lgG} 36.93(\mathrm{GPL} / \\
\mathrm{mL}) \\
\text { IgM } 4.36(\mathrm{MPL} / \mathrm{mL})\end{array}$ & $\begin{array}{l}\lg A \mid 3.62(\mathrm{APL} / \mathrm{mL}) \\
\operatorname{lgG} \mid 7.78(\mathrm{GPL} / \mathrm{mL}) \\
\operatorname{lgM} 30.05(\mathrm{MPL} / \mathrm{mL})\end{array}$ \\
\hline
\end{tabular}


Table 2 (Continued).

\begin{tabular}{|l|c|c|c|c|c|}
\hline Characteristic & Patient I & Patient 2 & Patient 3 & Patient 4 & Patient 5 \\
\hline ANA & Negative & Negative & Negative & Negative & Negative \\
\hline $\begin{array}{l}\text { Interleukin-6 (pg/ } \\
\mathrm{mL})(0-7)\end{array}$ & 20.93 & 5.26 & 6.75 & 92.58 & 63.19 \\
\hline $\begin{array}{l}\text { Anti-jo-I (Relative } \\
\text { Level) }\end{array}$ & $\begin{array}{l}\text { Feb. 107 } \\
\text { Mar. 27 88 } \\
\text { May 09 76 } \\
\text { Jun. 18 65 } \\
\text { Jul. 15 63 } \\
\text { Jul. 30 55 }\end{array}$ & Negative & Negative & Negative & Negative \\
\hline
\end{tabular}

Note: The data is the first test result after the patient's RT-PCR diagnosis except for anti-jo-I.

chest CT showed fibrous proliferative foci in both upper lobes of the lung. He was transferred to intensive care on 06 February 2020. The patient's body temperature was as high as $39.4^{\circ} \mathrm{C}$, and oxygenation decreased, as low as $70 \%$.

IgA-RF was found in three non-severe patients and IgMRF in the other two severe patients (Table 1). None of the five patients had a history of rheumatoid arthritis (RA) and the CCP test was negative. The IgA-RF level of the first patient continued to increase after recovery, far beyond the reference range, in the following several visits to the hospital. In the latest test, antibody levels in the first patient dropped but were still far above the recommended level. In the other two patients in the non-severe group, the antibody level showed the same trend as in the first patient. The level of IgM-RF was significantly increased in two severe patients, the level of IgG-RF was slightly increased, and the IgA-RF was within the normal range. The dynamic changes of RFs in these five patients are shown in Figure 1.

\section{Discussion}

It has not been reported that these RFs were associated with COVID-19 patients, The RF was monitored in five patients and found that their RF levels continued to rise over the following months, the patients with symptom have significantly higher levels of RF than asymptomatic. The rheumatoid factors were not only present in the acute phase of COVID, but also present during the time of recovery.

The first patient also produced anti-Jo-1 antibody (Table 2), which was closely related to myositis, and its titer was related to the severity of the disease. ${ }^{3}$ This may be why IgA-RF is much higher in the first patient than in the second patient. The anti-jo-1 antibody is one of the anti-ENA antibodies and directed against histidyl-tRNA synthetase account for about $80 \%$ of all cases of antisynthetase syndrome. ${ }^{4,5}$ In some cases, anti-Jo-1 antibodies were present in conjunction with interstitial pneumonia. ${ }^{6}$

Rheumatoid factors are antibodies directed against the $\mathrm{Fc}$ region of $\mathrm{IgG}$, one of the autoantibodies associated with rheumatoid arthritis (RA). RF may be caused by the stimulation of virus, mycoplasma and other persistent infections and can be divided into IgA-RF, IgG-RF, IgM-RF and IgE-RF. In the first patient, the level of IL-6 was higher than normal, and IL-6 could induce IgA production. $^{7}$ IgA-RF production was observed at the local virus-specific immune response site, ie, in mediastinal lymph nodes and in the lung. ${ }^{8}$ The significance of these antibodies is not fully understood. There are some studies that described rheumatological and nonrheumatological autoantibodies in covid-disease. ${ }^{9}$ COVID-19 patients exhibit dramatic increases in autoantibody reactivities compared to uninfected controls. And it is speculated that SARS-CoV-2 can disrupt self-tolerance and trigger an autoimmune response through crossreaction with host cells so that patients will produce autoantibodies. ${ }^{10,11}$ In a study, the authors found that 21 out of 50 tissue antigens had moderate to solid reactions with SARS-CoV-2 antibodies, which fully demonstrated the existence of cross-reactions between SARS-CoV-2. ${ }^{12}$ Autoantibodies are often detected in COVID-19 patients, which may reflect the pathogenic effect of immune disorders, but the correlation between autoantibodies and poor prognosis requires further multicenter studies. In our study, rheumatoid factor is related to the severity of the disease. 
patient 1

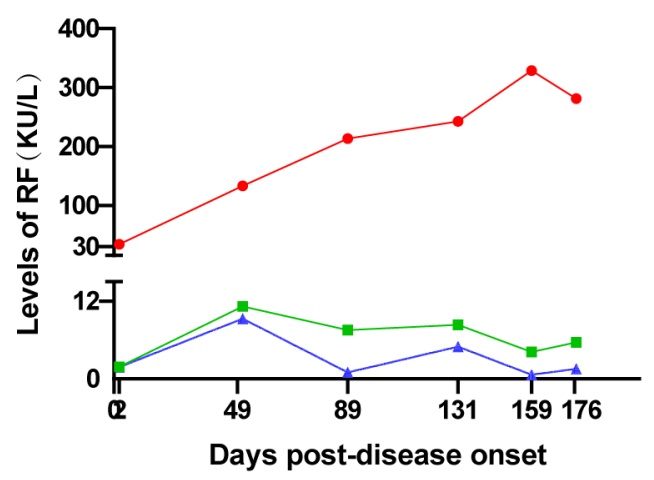

patient 3

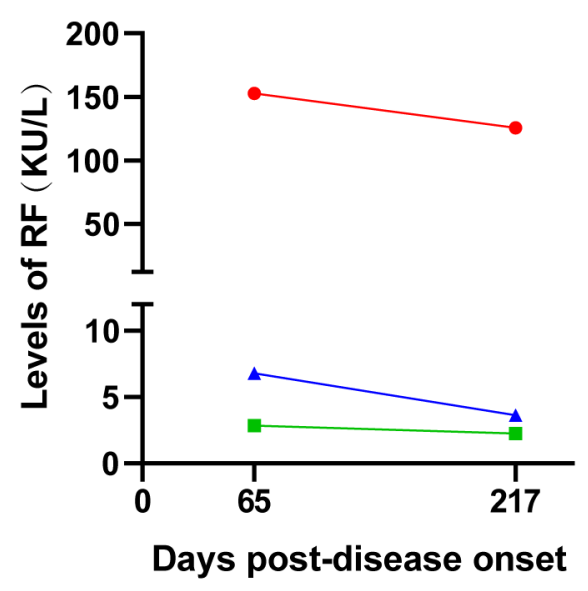

patient 2

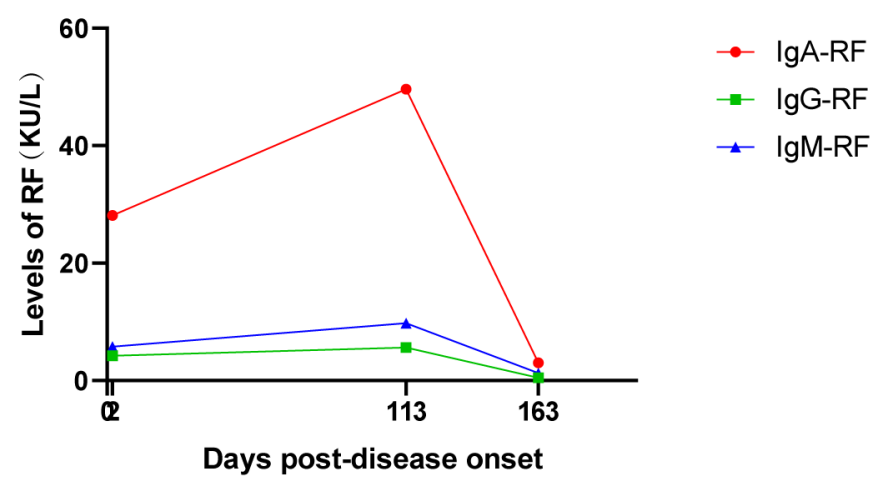

patient 4

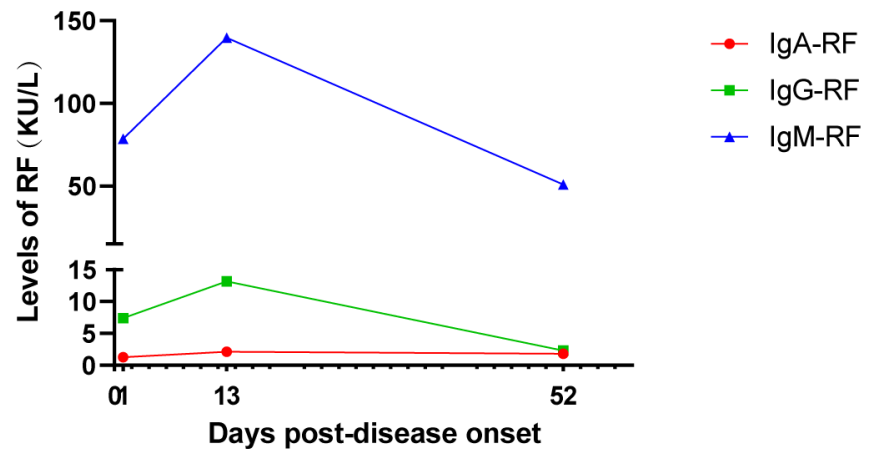

\section{patient 5}

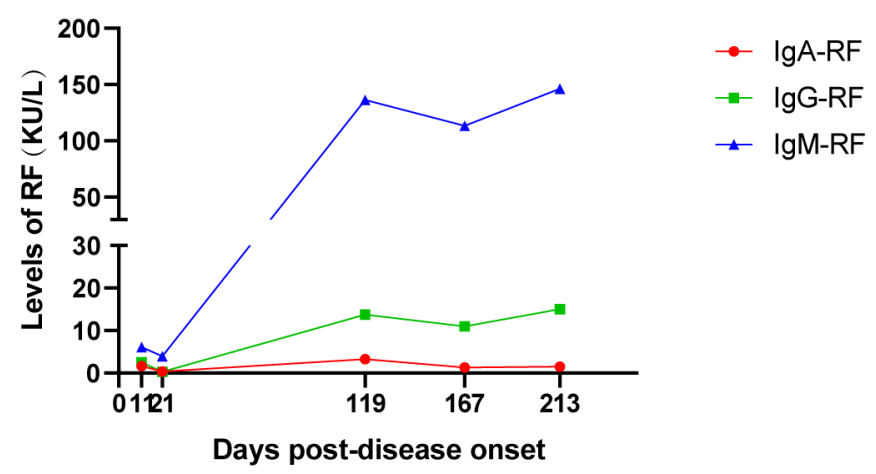

Figure I Dynamic changes in the levels of rheumatoid factor antibodies during COVID-19 among five patients.

The situation of severe patients was different from that of non-severe patients, whose IgA-RF was normal and IgM-RF was significantly increased, and it continued to rise in the following months. With the remission of the patient's disease, the level of IgM-RF decreased gradually, indicating that the level of IgM-RF may be associated with the severity of 
the disease. The appearance of RF presents a delayed nature. Antibody levels are associated with disease progression and decline in patients as they improve. Unlike the antiphospholipids, anticardiolipin IgA antibodies as well as anti$\beta 2$-glycoprotein I which appear in acute stage of COVID last for a short time, RF can occur both acute stage and late stage of diseases and last a long time, which may have longterm effects on patients. The clinical significance of these antibodies was unknown, it is necessary to continue to monitor the levels of these autoantibodies in COVID patients.

\section{Conclusion}

We found that delayed rheumatoid factors (RF) was present in COVID patients without a history of rheumatoid arthritis and that the subtype of autoantibodies was associated with the severity of the patient's disease. IgA-RF appears in non-severe patients, and IgM-RF and IgG-RF in severe patients, and both IgA-RF and IgM-RF antibody levels drop as the patient recovers, and these autoantibodies last for a longer time. This may be the reason why anti-rheumatic drugs can be used in patients with COVID-19. The long-term effects of these rheumatoid factors (RF) on COVID patients need further characterization.

\section{Data Sharing Statement}

The data of this study are in the article.

\section{Acknowledgments}

This work was supported by grants from National Natural Science Foundation of China (81272372) and by Zhongnan Hospital of Wuhan University Science, Technology and Innovation Seed Fund (znpy2016033).

\section{Disclosure}

The authors declare no conflict of interest in relation to the submission.

\section{References}

1. Cheng C, Li C, Zhao T, et al. COVID-19 with rheumatic diseases: a report of 5 cases. Clin Rheumatol. 2020;39(7):2025-2029. doi:10.1007/s10067-020-05160-x

2. Nowak UM, Newkirk MM. Rheumatoid factors: good or bad for you? Int Arch Allergy Immunol. 2005;138(2):180-188. doi:10.1159/ 000088794

3. Zamora AC, Hoskote SS, Abascal-Bolado B, et al. Clinical features and outcomes of interstitial lung disease in anti-Jo-1 positive antisynthetase syndrome. Respir Med. 2016;118:39-45. doi:10.1016/j. rmed.2016.07.009

4. Nozue T, Toyoshima M, Fukada A, Suda T. Anti-Jo-1 antibody-positive interstitial pneumonia in an elderly patient with congenital rubella syndrome. Intern Med. 2019;58(14):2063-2066. doi:10.2169/internalmedicine.2454-18

5. Jeffrey T, Suren J, James B. A case of adult dermatomyositis associated with parainfluenza virus infection and Jo-1 antibody. Int J Rheum Dis. 2017;20.

6. Tillie-Leblond I, Wislez M, Valeyre D, et al. Interstitial lung disease and anti-Jo-1 antibodies: difference between acute and gradual onset. Thorax. 2008;63(1):53-59. doi:10.1136/thx.2006.069237

7. Kd Y, Nr P, S W. IL-6 is a potent cofactor of IL-1 in IgM synthesis and of IL-5 in IgA synthesis. J Immunol. 1989;143.

8. Fazekas G, Rosenwirth B, Dukor P, Gergely J, Rajnavölgyi É. Kinetics and isotype profile of rheumatoid factor production during viral infection: organ distribution of antibody secreting cells. Scand J Immunol. 1996;44(3):273-284. doi:10.1046/j.1365-3083.1996.d01307.x

9. Pascolini S, Vannini A, Deleonardi G, et al. COVID-19 and immunological dysregulation: can autoantibodies be useful? Clin Transl Sci. 2021;14(2):502-508. doi:10.1111/cts. 12908

10. Liu Y, Sawalha AH, Lu Q. COVID-19 and autoimmune diseases. Curr Opin Rheumatol. 2021;33(2):155-162. doi:10.1097/ BOR.0000000000000776

11. Halpert G, Shoenfeld Y. SARS-CoV-2, the autoimmune virus. Autoimmun Rev. 2020;19(12):102695. doi:10.1016/j. autrev.2020.102695

12. Vojdani A, Kharrazian D. Potential antigenic cross-reactivity between SARS-CoV-2 and human tissue with a possible link to an increase in autoimmune diseases. Clin Immunol. 2020;217:108480. doi:10.1016/ j.clim. 2020.108480
Journal of Inflammation Research

\section{Publish your work in this journal}

The Journal of Inflammation Research is an international, peerreviewed open-access journal that welcomes laboratory and clinical findings on the molecular basis, cell biology and pharmacology of inflammation including original research, reviews, symposium reports, hypothesis formation and commentaries on: acute/chronic inflammation; mediators of inflammation; cellular processes; molecular mechanisms; pharmacology and novel anti-inflammatory drugs; clinical conditions involving inflammation. The manuscript management system is completely online and includes a very quick and fair peerreview system. Visit http://www.dovepress.com/testimonials.php to read real quotes from published authors. 